\title{
Neophobia in wild and laboratory mice ${ }^{1,2}$
}

TERRY D. MEDDOCK, ${ }^{3}$ and DON R. OSBORN III, ${ }^{4}$ Department of Psychology Miami University, Oxford, Ohio 45056

Thirteen laboratory mice and nine wild mice of the species Mus musculus were used to determine the effects of domestication on neophobic reaction. The neophobic situation was the insertion of a small plastic horse in the S's home cage for a period of $5 \mathrm{~min}$. Five such tests were conducted over a two-month period. The wild mice were found to be more hesitant in their first approach and also made contact with the novel object less often than did the laboratory mice. These results suggest that the strength of the neophobic reaction has been reduced in the behavioral repertoire of the laboratory mouse.

There are numerous behavioral and physiological differences in wild and laboratory rats. Richter (1959), working with both varieties of Norway rats, noted that the adrenal glands are smaller and less effective in the laboratory rat. He also pointed to other differences in the functioning of the endocrine systems of the two animals. Related to these facts is Barnett's $(1958,1963) \mathrm{ob}-$ servation that wild rats exhibit more avoidance reactions to novel objects than do their laboratory brethren. He further states that behavioral differences such as these are not universal among animals, e.g., the house mouse (Mus musculus) displays a capricious and unpredictable behavior in a neophobic situation.

The aim of this research is to determine whether the effects of domestication observed in rats are also characteristic of mice.

$$
\text { METHOD }
$$

The Ss were 22 mice of the species Mus musculus. The 13 laboratory mice were eight females and five males of the inbred strain $\mathrm{CH} 3$, subline 10 , from 2 to 3.5 months old. The nine wild mice, seven females and two males, were trapped in the Oxford, Ohio area. As this was part of a more comprehensive study of domestication, the Ss had experience in an open-field, activity wheel, stove pipe, and a neutral cage. Tests in these surroundings were conducted concurrently with the neophobia experiment.

Table 1

Mean Latency of First Approach and Mean Number of Approaches

Mean Latency

of

First Approach (in sec)

Mean Number

of

Approaches

\begin{tabular}{|c|c|c|c|c|c|c|}
\hline \\
\hline \multirow{3}{*}{$\begin{array}{l}\text { Laboratory } \\
\text { Mice } \\
\quad \mathrm{N}=13\end{array}$} & $\overline{\mathrm{X}}$ & 6.8 & \multirow{2}{*}{$\begin{array}{l}t=4.67 \\
d f=20\end{array}$} & $\overline{\mathrm{X}}$ & 22.9 & $t=7.07$ \\
\hline & SD & 6.5 & & SD & 7.2 & $\mathrm{df}=20$ \\
\hline & & & $\mathrm{p} \quad .001^{*}$ & & & p $\quad .001 *$ \\
\hline Wild Mice & $\overline{\mathrm{X}}$ & 15.2 & & $\overline{\mathrm{X}}$ & 13.0 & \\
\hline$N=9$ & SD & 7.1 & & SD & 9.5 & \\
\hline
\end{tabular}

*Probabilities are for a two-tailed test
The Ss were housed in individual cages $5 \times 5 \times 6$ in. constructed of pine wood and hardware wire. The cages were placed on a rack so that no mouse could see any other mouse. Food and water were constantly available. The light cycle (12 M-11 $\mathrm{PM})$ and temperature ( $70 \mathrm{deg} F)$ of the laboratory were kept constant.

The neophobic object was a small tan plastic horse 3.5 in. high, $2 \mathrm{in}$. long and $.5 \mathrm{in}$. wide. A table was used for testing purposes.

The testing procedure consisted of placing the S's home cage on the testing table for a period of $1 \mathrm{~min}$ before inserting the plastic horse in the cage. A record was kept of the latency of S's first approach to the object during the 5 min testing period. An "approach" was defined as any head contact with the object (such as sniffing, nudging, pushing, or biting) within the $5 \mathrm{~min}$ trial. $\mathrm{E}$ was seated quietly $3 \mathrm{ft}$ from the cage and noted any unusual behavior of the mouse during each testing trial. After each trial, the object was removed and $S$ returned to its maintenance rack. Each $\mathrm{S}$ was given five such testing trials, spaced at approximately 11 day intervals.

\section{RESULTS}

The data on neophobic reaction are presented in Table 1.

The results show that wild and laboratory mice of the species Mus musculus react differently in a neophobic situation. Differences between sexes did not appear to be a factor in this experiment. The wild mice displayed a more hesitant, cautious approach to the neophobic object which is reflected in their low number of approaches and high latency of first approach.

\section{CONCLUSIONS}

Possible defects in the experiment may have been the wild mice's experience of being trapped or the giving of other tests in conjunction with those described herein. On the positive side, both groups were habituated to the laboratory environment for three weeks before any tests were given in order to minimize uncontrolled variables. Both groups were also equally exposed to the other tests. Handling of the S's was kept to a minimum.

Neophobia is the avoidance of a novel stimulus in an otherwise familiar situation. Barnett $(1958,1963)$ has pointed out that such behavior in wild rats has survival value in saving them from the perils of traps and poison. Our data suggests that this is also an aspect of wild mouse behavior. Domestication, apparently, has served to dampen this form of behavior.

\section{REFERENCES}

BARNETT, S. A. Experiment on "neophobia" in wild and laboratory rats. British Journal of Psychology, 1958, 49, 195-201.

BARNETT, S. A. The rat. Chicago, Illinois: Aldine Publishing Company, 1963.

RICHTER, C. P. Rats, man, and the welfare state. American Psychologist, $1959,14,18-28$.

1. This research was conducted under the auspices of the Undergraduate Research Committee at Miami University.

2. We would like to acknowledge the helpful assistance of Dr. Bruce $\mathrm{K}$. Alexander and Dr. Patrick J. Capretta.

3. Currently at the University of Illinois.

4. Currently at Northwestern University. 